\title{
Operational Model
}

National Cancer Institute

\section{Source}

National Cancer Institute. Operational Model. NCI Thesaurus. Code C142622.

A design model that lays out how a study will be carried out in order to fulfill its objectives. 